\title{
Sistem Penjualan DRW Skincare Berbasis e-Commerce di Kota Samarinda
}

\author{
Damar Nurcahyono ${ }^{1)}$, Noor Alam Hadiwijaya ${ }^{2)}$ \\ ${ }^{1,2)}$ Teknologi Informasi, Politeknik Negeri Samarinda \\ Jalan Dr Ciptomangunkusumo Kampus Gunung Panjang, Samarinda 75131, Kalimantan Timur, Indonesia \\ ${ }^{2)}$ damarnc@polnes.ac.id ${ }^{1)}$, alamhadiwijaya@gmail.com ${ }^{2)}$
}

\begin{abstract}
Abstrak - Di saat ini semua kebutuhan sudah bisa didapatkan dengan cara yang mudah dan cepat karena ada teknologi yang semakin berkembang dengan cepat, sebelum ada teknologi dulu jika kita ingin membeli suatu barang maka kita membeli langsung kepada penjual atau toko - toko yang tersedia. Tapi dengan teknologi yang semakin cangih dan ilmu pengetahuan yang semakin maju sekarang kita tidak perlu lagi atau tidak perlu susah karena sekarang sudah terdapat toko - toko yang menjual barang melalui internet yaitu dengan cara E-Commerce atau yang biasa dikenal dengan toko online. Oleh sebab itu penulis ingin membuat sebuah karya tulis tantang toko online yang bisa menjual kommetik atau skincare dengan mudah dan cepat. Aplikasi ini dibuat dengan cara bertahap mulai dari analisa awal permasalahan, desain sistem, pembuatan sistem sampai perbaikan atau perawatan system. Agar lebih mudah didalam hal pengerjaannya, dan menggunakan tools PHP dan MySql untuk databasenya, aplikasi ini di buat agar konsumen dapat terbantu didalam melakukan transaksi sehingga tidak perlu lagi meluangkan waktu datang ketempat langsung untuk membeli skincare.
\end{abstract}

Kata-kata Kunci - Skincare, E-Commerce, toko online

\section{PENDAHULUAN}

Pada saat ini internet menjadi sarana penting didalam kehidupan manusia atau masyarakat karena internet sangatlah penting untuk kebutuhan sehari-hari dengan adanya internet manusia atau masyarakat akan dengan mudah mendapatkan berita atau hal lain yang mereka inginkan atau butuhkan dengan cara yang cepat dan mudah tanpa membuang-buang waktu. Seiring dengan kemajuan zaman yang semakin pesat maka masyarakat menutut teknologi harus lebih maju agar semua hal atau kegiatan yang memakan waktu bisa dilakukan dengan efisen agar tidak membuang-buang waktu yang biasanya digunakan untuk beraktivitas maupun berkerja sehari-hari Kemajuan yang sangat pesat didunia ini menuntut banyaknya perusahaan agar mengikuti kemajuan teknologi yang ada di dunia ini dengan cara menjadi perusahaan yang bergerak dibidang E-Commerce dalam berjualan misalnya toko-toko yang biasanya menawarkan barang kepada pelanggannya dengan cara menarik pelanggan agar datang langsung ketoko tersebut,namun hal itu sudah tidak diperlukan lagi mengingat zaman yang sudah semakin maju dan dibantu dengan kemajuan teknologi yang begitu pesat sekarang untuk membeli sebuah barang masyarakat tidak perlu lagi datang langsung ketempat atau ke toko-toko tersebut karena dengan jika toko-toko sudah bergerak dibidang $e$ commerce, masyarakat yang ingin membeli barang bisa langsung membeli tanpa harus datang ketempatnya langsung dengan bantuan komputer maupun smartphone yang sudah terkoneksi kedalam internet, hal itu dapat memudahkan masyarakat jika ingin membeli barang tanpa membuang waktunya. Permasalahan yang dihadapi sekarang ini adalah bagaimana cara penjual bisa mejualkan berbagai produknya dengan cara mudah dan bisa diakses oleh masyarakat luas, Perbandingan dengan cara berjualan yang masih konvesional dengan era sekarang ini adalah kita dapat menjualkan barang - barang kita dengan cara lebih leluasa dan meringankan beban para pembeli jika ingin memberi barang tidak perlu lagi datang ketoko tersebut. Oleh sebab itu sebaiknya para penjual dijaman sekarang ini sudah bisa menggunakan metode E-Commerce, yang merupakan salah satu sistem yang banyak digunakan oleh orang -orang yang ingin berbelanja namun tidak ada waktu untuk membeli barang - barang secara langsung oleh sebab itu adanya toko online merupakan suatu trobosan tersendiri didalam ilmu teknologi.

\section{METODE}

\section{Metode Penelitian}

Metode yang digunakan didalam penelitian menggunakan SDLC waterfall adalah suatu proses yang bersifat bertahap seperti air terjun yang mengalir kebawah melewati fase perencanaan, pemodelan, implementasi dan pengujian lebih terurut dimana jika nanti terjadi sebuah kesalahan maka sistem akan diperbaiki dengan cara bertahap dan pemeliharaan lebih mudah. 


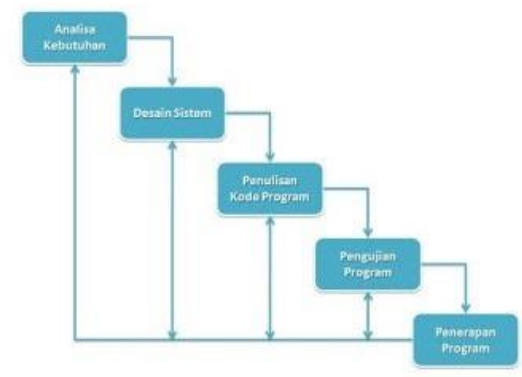

Gambar 1 SDLC Waterfall

1. Analisa Kebutuhan
Awal dari penelitian mengumpulkan kebutuhan yang diperlukan kemudian dilakukan analisis dan didefinisikan program yang akan dibangun sehingga didalam pengerjaan program akan lebih lengkap.

2. Desain Sistem

Pada tahapan desain sistem adalah pengembangan dari analisis yang ada sehingga dibuatkan desain secara keseluruhan dan menentukan alur perangkat lunak hingga algoritma yang detail.

3. Penulisan Kode Program

Tahapan ini melakukan penulisan kode program atau melakukan implementasi dimana seluruh desain yang telah dilakukan diubah menjadi kode kode program yang akan diintregasikan menjadi system yang lengkap.

4. Pengujian

Tahapan ini melakukan pengujian program yang telah dibuat apakah aplikasi telah sesuai dengan desain dan fungsinya dan tidak terjadi kesalahan.

5. Penerapan Program

Penerapan program setelah dilakukan pengujian dan aplikasi telah sesuai dengan permintaan akan dilakukan instalasi dan perawatan serta perbaikan sistem sesuai dengan yang disetujui.

Masalah yang dihadapi oleh toko Skincare adalah masalah penjualan dimasa pandemic yang semakin sepi karena mengalami masalah didalam melakukan transaksi bertatap muka.

Penjualan Skincare dimasa pandemic dapat dilakukan secara online yaitu sistem E-Commerce sehingga tanpa melakukan tatap muka atau bertemu penjualan tetap dapat dilakukan. Masyarakat atau konsumen cukup berada dirumah sudah dapat berbelanja kebutuhan skincare.
Electronic Commerce (E-commerce) adalah sebuah media pembelian atau penjualan yang dilakukan melalui sistem elektronik. Yang dimana para penjual maupun pembelinya tidak bertemu tetapi pembelian masih bisa dilakukan dengan cara memakai alat elektronik untuk melakukan pemesanan seperti handphone ataupun komputer.

E-Commers adalah suatu konsep penjualan yang dilakukan melalui internet atau World Wide Web. PHP adalah suatu Bahasa pemrograman yang banyak digunakan oleh pengguna web membuat aplikasi atau system. My $S Q L$ adalah salah satu aplikasi database atau DBMS (Database Management System) yang banyak digunakan oleh pengguna web.

\section{HASIL DAN PEMBAHASAN Analisa Perancangan}

1. Rancangan Sistem Admin

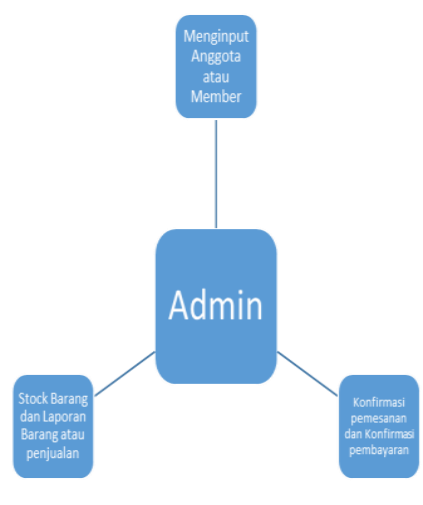

Gambar 2 Diagram Admin

Gambar 2. Merupakan Admin yang mempunyai tugas untuk melakukan registrasi anggota atau member, meninputkan stock barang atau produk, membuat laporan, mengkonfirmasi pemesanan dan pembayaran.

\section{Rancangan Sistem User atau Member}

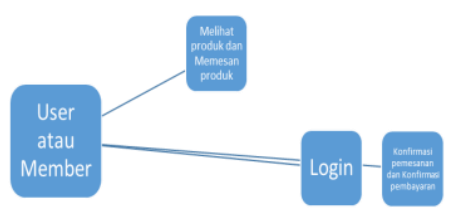

Gambar 3 Diagram Member

Gambar 3. Adalah diagram member atau user dapat melakukan pembelian atau pemesanan tetapi terlebih dahulu harus Login apabila tidak login maka hanya dapat melihat produk tanpa bias melakukan pemesanan atau pembelian. 


\section{Implementasi}

Tampilan awal atau depan dari sistem $e$ commerce DRW Skin Samarinda.

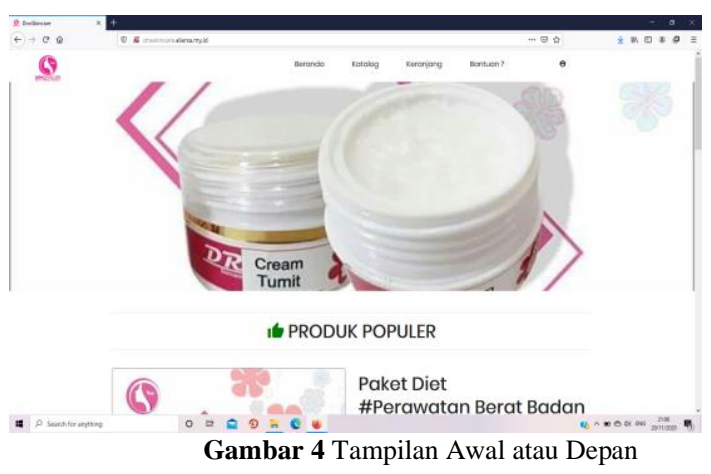

Tampilan produk - produk dari Skincare DRW Samarinda dapat dilihat pada Gambar 5

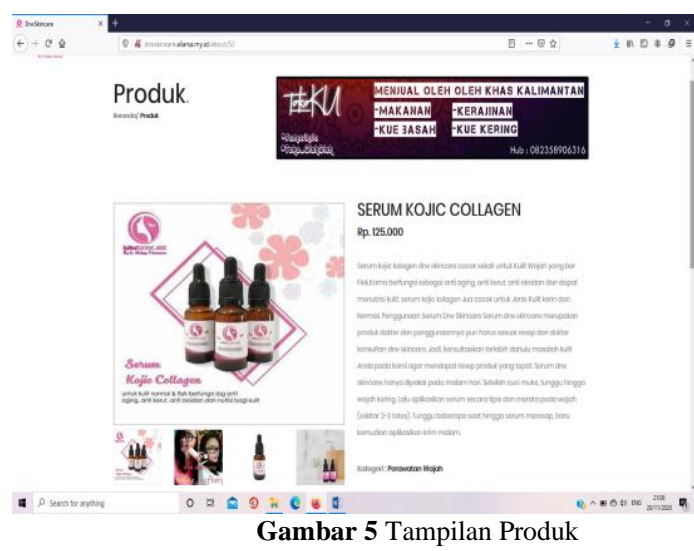

Jika member atau user berminat melakukan pembelian produk maka pada Gambar 6 . Diarahkan untuk melakukan login sebagai anggota.

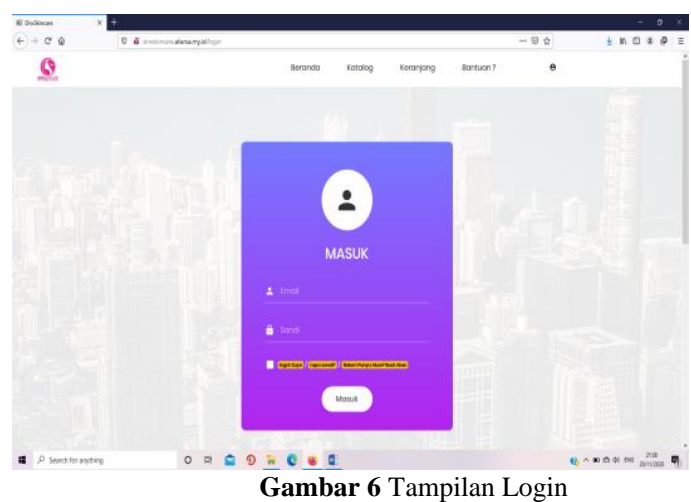

Jika belum mamjadi member maka akan diarahkan terlebih dulu untuk melakukan pendaftaran. Seperti tampak pada Gambar 7, berikut ini

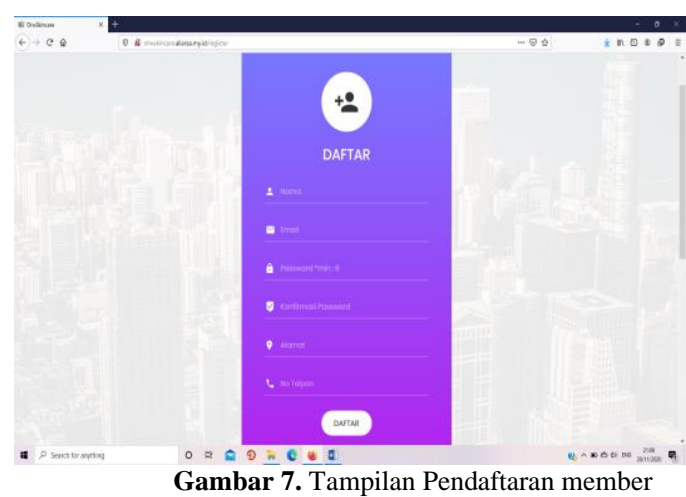

Setelah terjadi transaksi maka tampilan transaksi dari produk yang dipesan dan jumlah yang harus dibayar.

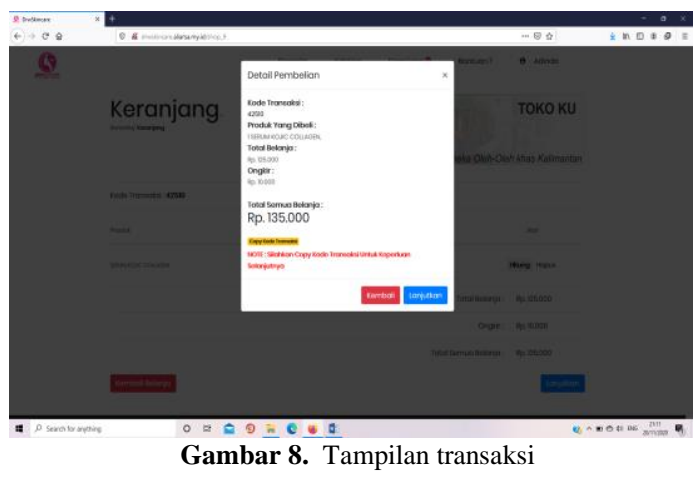

\begin{tabular}{lccc}
\multicolumn{1}{c}{ Setelah } & itu & tampilan & konfirmasi \\
pembayaran & apabila & telah & melakukan \\
pembayaran. & & &
\end{tabular}
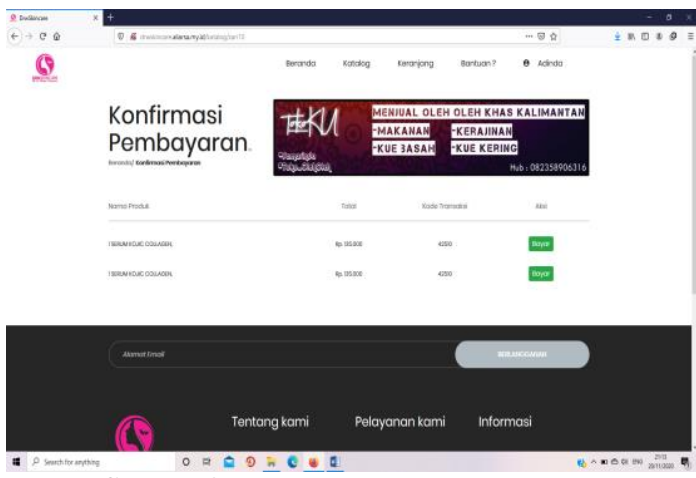

Gambar 9 Tampilan Konfirmasi pembayaran

\section{KESIMPULAN}

Aplikasi Sistem penjualan drw skincare berbasis e-commerce di kota samarinda dapat berjalan dengan baik dan membantu didalam proses penjualan secara online dimasa pandemic Covid 19. Produk yang dijual dapat dibeli dari beberapa daerah secara online sehingga meningkatkan penjualan dan mempermudah melakukan pemasaran karena dengan system online dapat dilihat oleh masyarakat tanpa ada batasan. 
JUST TI: (Jurnal Sains Terapan Teknologi Informasi) 13, Januari, 2021: 37-40

ISSN: 2579-4510(online) ISSN: 2085-6458(print)

\section{REFERENSI}

[1] Ahmia, M., \& Belbachir, H. (2018). " Sistem Penjualan Berbasis Web (E-Commerce) Pada Tata Distro Kabupaten Pacitan ". Indian Journal of Pure and Applied Mathematics, 49(3), 549-557. https://doi.org/10.1007/s13226-018-0284-5.

[2] Fitri, R. S., Rukun, K., \& Dwiyani, N. (2014). PERANCANGAN DAN IMPLEMENTASI SISTEM INFORMASI PENJUALAN KOMPUTER DAN ACCESSORIES PADA TOKO MUJAHIDAH COMPUTER BERBASIS WEB Rahmi. Inflammation and Cell Signaling, 2(2), Jurnal Vokasional Teknik Elektronika \& Informatika. https://doi.org/10.14800/ics.95

[3] Mustofa, A., \& Mutmainah, M. (2017). "Perancangan E-Commerce Penjualan Komputer Dan Alat Elektronik Berbasis Web Pada Toko Damar Komputer Pringsewu", Jurnal TAM (Technology Acceptance Model), 4(0), 62-67. Retrieved from http://ojs.stmikpringsewu.ac.id/index.php/JurnalTa $\mathrm{m} /$ article/view/38

[4] Rahmidani, R. (2015). "Penggunaan E-Commerce Dalam Bisnis Sebagai Sumber Keunggulan Bersaing Perusahaan. Penggunaan E-Commerce Dalam Bisnis Sebagai Sumber Keunggulan Bersaing Perusahaan”, (c), 345-352. Retrieved from http://fe.unp.ac.id/sites/default/files/unggahan/26. Rose Rahmidani (hal 344-352).pdf

[5] Setiadi, A., \& Alfiah, F. (2016). "Sistem Penjualan Spare Part Toko Ajm Motor Menggunakan Ci Berbasis Arsitektur Mvc”. Simetris : Jurnal Teknik Mesin, Elektro Dan Ilmu Komputer, 7(2), 575. https://doi.org/10.24176/simet.v7i2.770

[6]Rahmawati, N., \& Mulyono, H. (2016). Analisis dan Perancangan Sistem Informasi Pemasaran berbasis Web pada Toko Billy. Jurnal Manajemen Sistem Informasi, 1(2), 104-116. Retrieved from http://jurnalmsi.stikom-

db.ac.id/index.php/jurnalmsi/article/view/44/38 